\title{
AXL Gene Amplification
}

National Cancer Institute

\section{Source}

National Cancer Institute. AXL Gene Amplification. NCI Thesaurus. Code C141275.

A molecular genetic abnormality indicating the presence of multiple copies of the AXL gene. 